\title{
Bioaerosol concentration in the air surrounding municipal solid waste landfill ${ }^{1}$
}

\author{
Stężenie bioaerozolu w powietrzu wokół \\ składowiska odpadów komunalnych
}

\author{
* Dr Marcin Kaźmierczuk, Department of Ecotoxicology, mgr Anna Bojano- \\ wicz-Bablok. Waste Management Department, Institute of Environmental \\ Protection - National Research Institute, Krucza 5/11d St., 00-548 \\ Warsaw, phone: +48 22 3750636, +4822 3750507, e-mail: \\ Marcin.Kazmierczuk@ios.edu.pl,Anna.Bojanowicz-Bablok@ios.edu.pl
}

Keywords: municipal solid waste landfill, range of bioaerosol emission, Enterobacteriaceae, haemolytic bacteria, yeasts and yeastlike fungi

Słowa kluczowe: składowisko odpadów komunalnych, zasięg emisji bioaerozolu, Enterobacteriaceae, bakterie hemolizujące, drożdże i grzyby drożdżopodobne

\section{Abstract}

The research was focused on the assessment of the bioaerosol concentration in the air of the Machnacz municipal solid waste landfill and its surrounding. Evaluation of air pollution was made during the autumn season. In the air collected with impactor sampler, the levels of indicator microorganisms - bacteria from the Enterobacteriaceae family, $\beta$-haemolytic bacteria, yeasts and yeast-like fungi - were determined. The proposed indicator microorganisms are different from those recommended by Polish Norm PN 89/Z-04111.01. This highlights the specific character of our method. Such selection of indicators allows not only assessing the air pollution of the landfill site but also determining the range of its impact on the surroundings. The results indicate that the landfill is a source of emission and dispersal of bacterial and fungal aerosol, despite its correct management and proper maintenance. The landfill influence on the microbial air quality reaches a distance of 1000-1200 $\mathrm{m}$ from the fence. The range of the influence indicates it to be a potential hazard for neighbouring residents.

(C) IOŚ-PIB

\section{INTRODUCTION}

Municipal solid waste landfills are sources of microbial air pollution [Huang et al. 2002, Kaźmierczuk et al. 2004, Butarewicz, KowalukKrupa 2004, Małecka-Adamowicz et al. 2007, Zmysłowska et al. 2007, Kummer, Thiel 2008, Berleć et al. 2009, Breza-Boruta, Paluszak 2009]. Microorganisms are transported from the landfill to the atmosphere with the wind. Their survival depends on their resistance, meteorological conditions, air pollution and time spent in the atmosphere [Marthi et al. 1990]. According to various studies, the range of bioaerosol emission is considerable and may reach 1000-1200 $\mathrm{m}$ from the border of the site [Kulig, Ossowska-Cypryk 1999, Traczewska, Karpińska-Smulikowska 2000, Adamiak et al. 2001, Frączek et al. 2003, Traversi et al. 2011]. Emissions from

\section{Streszczenie}

Przeprowadzono badania stężenia bioaerozolu pochodzacego ze składowiska odpadów komunalnych w Machnaczu w okresie jesiennym metodą zderzeniową. Do oceny zasięgu oddziaływania składowiska na otoczenie zaproponowano wykorzystanie własnej metody, opartej na wybranych mikroorganizmach wskaźnikowych: bakteriach z rodziny Enterobacteriaceae, bakteriach hemolizujących typu beta oraz drożdżach i grzybach drożdżopodobnych. Katalog wybranych mikroorganizmów wskaźnikowych nie pokrywa się ze standardowa Polską Norma PN 89/Z-04111.01. Stanowi to o pewnej specyfice zastosowanej metody pomiaru. Taki wybór wskaźników pozwala bowiem nie tylko ocenić poziom zanieczyszczenia powietrza w obrębie samego składowiska, ale umożliwia także określenie zasięgu oddziaływania składowiska na otoczenie. Uzyskane wyniki pozwalają stwierdzić, że badane składowisko jest istotnym źródłem emisji i rozprzestrzeniania się aerozolu bakteryjnego i grzybowego pomimo prawidłowej eksploatacji i poprawnie prowadzonych procesów technologicznych składowania odpadów. Zasięg oddziaływania składowiska na stan sanitarny powietrza atmosferycznego ocenia się na 1000 - 1200 m, licząc odległość od ogrodzenia obiektu. Tak duża odległość może stanowić potencjalne zagrożenie dla okolicznych mieszkańców.

\footnotetext{
${ }^{1}$ The research was conducted through grant no. N N305 2134 37, 'Economic assessment of external effects of

municipal waste landfilling', financially supported by the Ministry of Science and Higher Education.
}

waste facilities are issues from occupational health and safety as well as environmental hygiene aspects [Kummer, Thiel 2008, Giusti 2009]. Airborne microorganisms may cause respiratory diseases and other health effects in the facility workers and neighbouring residents [Wouters et al. 2002, Douwes et al. 2003, Heldal et al. 2003, Curtis et al. 2006, Schrapp, Al-Mutairi 2010]. A large part of the particles isolated from landfill air is within a respirable size range: $40 \%$ of the bacteria and $80 \%$ of the fungi [Rahkonen et al. 1990]. Respirable fractions are of particular importance in the epidemiology of infectious diseases due to their easiness of dispersion and ability to infiltrate the respiratory system up to pulmonary alveoli. Despite the fact that most people spend much of 
their time inside the houses, the quality of outdoor air may have significant influence on the quality of indoor air [Shelton et al. 2002]. Indoor air in buildings located in close vicinity of municipal waste landfills may be polluted by microorganisms emitted from the landfill [Schrapp, Al-Mutairi 2010].

The composition and concentration of dispersed bioaerosol depend on the source of emission that includes pig, dairy and poultry farms, slaughterhouses, sewage treatment plants, composting facilities, refuse transfer stations, sorting and recycling plants and landfills. According to the Polish Norm PN 89/Z-04111.01, pertaining to all sources of emission, the indicator microorganisms are: total bacteria, actinobacteria, Pseudomonas fluorescens, $\alpha$ - and $\beta$-haemolytic staphylococci, and fungi. However, these microbial groups are not specific to landfill aerosols and some of them are widespread in the environment: Aspergilus fumigatus and actinomycetes are commonly released during composting [Douwes et al. 2003, Vilavert et al. 2009] whereas Cladosporium is one of the most prevalent genera in outdoor air and is independent of the type of environment [Kaarakainen et al. 2008]. Therefore, their application in the evaluation of the microbial air pollution may be very variable [Traczewska, Karpińska-Smulikowska 2000, Kaźmierczuk et al. 2004]. The indicators specific to bioaerosol emitted from municipal solid waste landfills have not been defined. Without proper indicator microorganisms, it is difficult to link microbial contamination measured at a distance from the facility to the specific waste management activity performed on a facility.

Therefore, in this research, the method for the assessment of microbial air pollution around municipal solid waste landfill was proposed based on the group of selected indicator microorganisms. On the basis of previous microbial sampling performed on different municipal solid waste landfills, the bacteria from the Enterobacteriaceae family, haemolytic bacteria able to induce haemolysis when grown on blood agar, and yeasts and yeast-like fungi were proposed as the indicators of microbiological pollution of air around solid waste landfills [Kaźmierczuk et al. 2004]. The reason for selecting these microorganisms as indicators was the fact that they were often isolated from samples of air collected on and around municipal landfills and, moreover, were not observed in the samples of ambient air. Previous microbiological studies have shown that bacteria from the Enterobacteriaceae family were commonly isolated from samples collected during bioaerosol testing on and around municipal solid waste landfills [Crook et al. 1987, Rahkonen et al. 1990, Kaźmierczuk 1996, Kaźmierczuk, Kalisz 1998-2000, Lis et al. 2004, Kaźmierczuk et al. 2004, Buczyńska et al. 2006, BrezaBoruta 2012] whereas their concentration in ambient air was relatively low [Kaźmierczuk et al. 2004, Zucker, Muller 2004, Donderski et al. 2005]. Moreover, it was observed that unseparated waste caused the highest exposure to Gram-negative bacteria during waste collection and sorting [Krajewski et al. 2001, Del Cimmuto et al. 2010, Park et al. 2011, Marchand et al. 2012]. Results of measurements indicated that the Enterobacteriaceae dominated the airborne Gram-negative bacterial flora [Zucker, Muller 2004]. Phenotypic analysis performed on cellulolytic bacteria isolated from 29 refuse samples of landfill site revealed that among Gramnegative isolates 24 strains out of 31 were assigned to the family of Enterobacteriaceae [Pourcher et al. 2001].

Numerous coccobacilli from the Enterobacteriaceae family are components of microflora of the gastrointestinal tract of humans and animals. However, the Enterobacteriaceae family also encompasses pathogenic bacteria that are relevant for the assessment of environmental hygienic condition and that are rarely isolated from the clean air [Shaffer, Lighthart 1997]. Some of these bacteria cause genitourinary tract infections (Escherichia coli), intestinal diseases (Salmonella, Shigella, Escherichia coli), blood infections (Yersinia enterocolitica) and also respiratory system infections (Klebsiella, Enterobacter) [Jarząb et al. 2011]. As opportunistic bacteria, they may cause diseases in the immunocompromised host organism [Zaremba, Borowski 2001]. They are also important producers of endotoxins that are the main pulmonary immunotoxicants [Dutkiewicz 1997, Liebers et al. 2008]. Due to the presence of coccobacilli in municipal waste, particularly in household waste, they have been considered as indicators appropriate for the assessment of microbiological air pollution around municipal solid waste landfills.

$\beta$-Haemolytic bacteria are pathogenic or relatively pathogenic bacteria [Menichetti 2005]. Their presence in the air may pose potential threat for human health. Microbiological studies of air sampled on municipal solid waste landfills indicated that their concentration was higher than in the control air [Kaźmierczuk, Kalisz 2001, Kaźmierczuk et al. 2004, Berleć et al. 2009, Burkowska et al. 2011]. Moreover, results of four year long studies around municipal solid waste landfill demonstrated that the air quality standards were exceeded by haemolytic bacteria in $76.9 \%$ of measurements [Frączek, Barabasz 2004].

The high level of yeasts and yeast-like fungi in air may be a potential health hazard, such as epidermal and systematic mycoses and allergic diseases. Moreover, indoor fungal concentrations are significantly influenced by the outdoor fungal concentrations [Shelton et al. 2002]. During studies of bioaerosol emission from the municipal solid waste landfill Kaźmierczuk [1996], the presence of fungi such as Alternaria, Cladosporium, Mucor, Rhizopus, Aspergillus, Fusarium and Penicillium was noted in each series of analyses on the Sabouraud agar. These fungi were observed in samples collected both downwind and upwind from the site. By contrast, the presence of yeasts and yeast-like fungi was noted only in the air collected within the landfill area and at a distance of $60-100 \mathrm{~m}$ from the fence downwind from the site. This pattern was confirmed in later studies [Kaźmierczuk, Kalisz 2001, Kaźmierczuk et al. 2004]. The results of other analyses also indicated that yeasts and yeast-like fungi dominated the atmospheric air influenced by the landfill, whereas their concentration in ambient air was low [Jurkiewicz et al. 1998, Lis et al. 1999, Lis et al. 2004].

With the proposed indicator microorganisms, it is possible to simultaneously determine their concentration in the air and assess the range of exposure for surroundings. The range of bioaerosol emission from the landfill is determined as the point at which the number of indicator microorganisms is equal to the number of these microorganisms in the control air. The extent of the impact of the landfill on the environment is determined on the basis of this indicator that has the maximum range. Additionally, presence of specific bacteria, yeasts and yeast-like fungi reflects the character of actual hazard for the neighbouring residents.

\section{MATERIAL AND METHODS}

\subsection{Characteristics of the landfill site}

The Waste Treatment Facility in Machnacz (N: 52 $38^{\prime} 17^{\prime \prime}$, E: $\left.18^{\circ} 57^{\prime} 30^{\prime \prime}\right)$ has been in operation since 1998. It has a capacity of processing 30,000 tonnes of municipal waste per year. The area of the landfill is 4.9 ha and the active area is 3.1 ha. Municipal waste is mechanically treated and the refuse is landfilled.

The surrounding area is rural with small villages. There is an open space to the north, west and south of the facility and a forest to the east. The nearest buildings are located at about 500-600 $\mathrm{m}$ to the south of the landfill and belong to the villages Pikutkowo and 
Słone. At a distance of about $1.2-1.5 \mathrm{~km}$ to the north, elevated above the landfill and the surrounding area, the densely populated Machnacz village is located. To the east, in the forest near the landfill, flows the small Zgłowiączka stream.

\subsection{Sampling locations}

The sampling sites were located (Fig. 1) on the landfill site close to the leachate reservoir ( $50 \mathrm{~m}$ inside from the fence), close to the fence $(0 \mathrm{~m})$ and at increasing distances of every $200 \mathrm{~m}$ from the fence. All samples were collected downwind.

The control sites were situated:

- during I series: $1200-1400 \mathrm{~m}$ and $1800 \mathrm{~m}$ upwind from the fence;

- during III series: $1500 \mathrm{~m}$ upwind from the fence.

Additionally, regardless of the wind direction, the concentration of indicator microorganisms in the air of the village of Wieniec Zdrój (N: 52 $39^{\prime} 26 "$ ", E: $\left.18^{\circ} 59^{\prime} 25^{\prime \prime}\right)$, located $3.5 \mathrm{~km}$ north-east from the landfill, was also examined (the village is outside the range of the map in Fig. 1). These data were used for determination of the concentration of bioaerosol in the control air. The sampling site was situated at such a distance from the landfill that the direct influence of the facility on the results of the analyses may be excluded.

\subsection{Sample collection and analysis}

Sampling was conducted three times during autumn 2010: 24.09.2010 (series I), 1.10.2010 (series II) and 4.10.2010 (series III). The sampling was performed according to the sampling strategy elaborated and applied at the Institute of Environmental ProtectionNational Research Institute (IEP-NRI). Viable airborne microorganisms were sampled with a MAS $100 \mathrm{ECO}^{\circledR} \mathrm{MERCK}$ impaction sampler according to Polish Norm PN 89/Z-04008. The sampling times (that depend on the predicted bacterial concentration in the air) were determined during preliminary sampling. The sampler was placed at $1.3 \mathrm{~m}$ above ground level. Three replicates of air samples were collected at each sampling location on three different culture media promoting selective growth of indicator microorganisms (all bioMerieux) with the incubation conditions as follows:

- bacteria from the Enterobacteriaceae family on MacConkey agar (MCK); 24 hours at $35^{\circ} \mathrm{C}$;

- $\beta$-haemolytic bacteria on Columbia agar with $5 \%$ of sheep blood (COS); 18 hours at $35^{\circ} \mathrm{C}$;

- yeasts and yeast-like fungi on Sabouraud agar with gentamicin and chloramphenicol (SGC2); from 2 to 5 days at $26^{\circ} \mathrm{C}$.

During sampling, relevant meteorological parameters (humidity, air temperature, wind direction and velocity) were registered. Wind velocity was measured with the LUTRON AM-4201 digital anemometer. The wind direction was determined using a compass based on the reaction of a foil ribbon to wind. Results of the observations were expressed on a 16-point compass rose. Air temperature and relative humidity were measured using a Diplex digital measuring device. Each measurement was made several times in each sampling point, and the results were averaged.

Immediately after sampling, the Petri dishes were transported to the IEP-NRI laboratory and incubated. After incubation, the number of colonies was determined. The number of colonies counted on the surface of the agar plates was corrected according to the Feller table and expressed as colony forming units per cubic metre of air $\left(\mathrm{cfu} / \mathrm{m}^{3}\right)$ :

- on the MCK medium, all bacteria-like colonies were counted with particular attention to the red-coloured ones;

- on the COS medium, only bacteria-like colonies surrounded by a zone of complete haemolysis were counted;

- on the SGC2 medium, only colonies of yeasts and yeast-like fungi were counted.

The sampled microorganisms were classified to the genus level: bacterial strains were identified by Gram staining and a biochemical API $20 \mathrm{E}$ microtest and yeast and yeast-like fungi were identified by biochemical API 20 C AUX microtest (both bioMerieux).

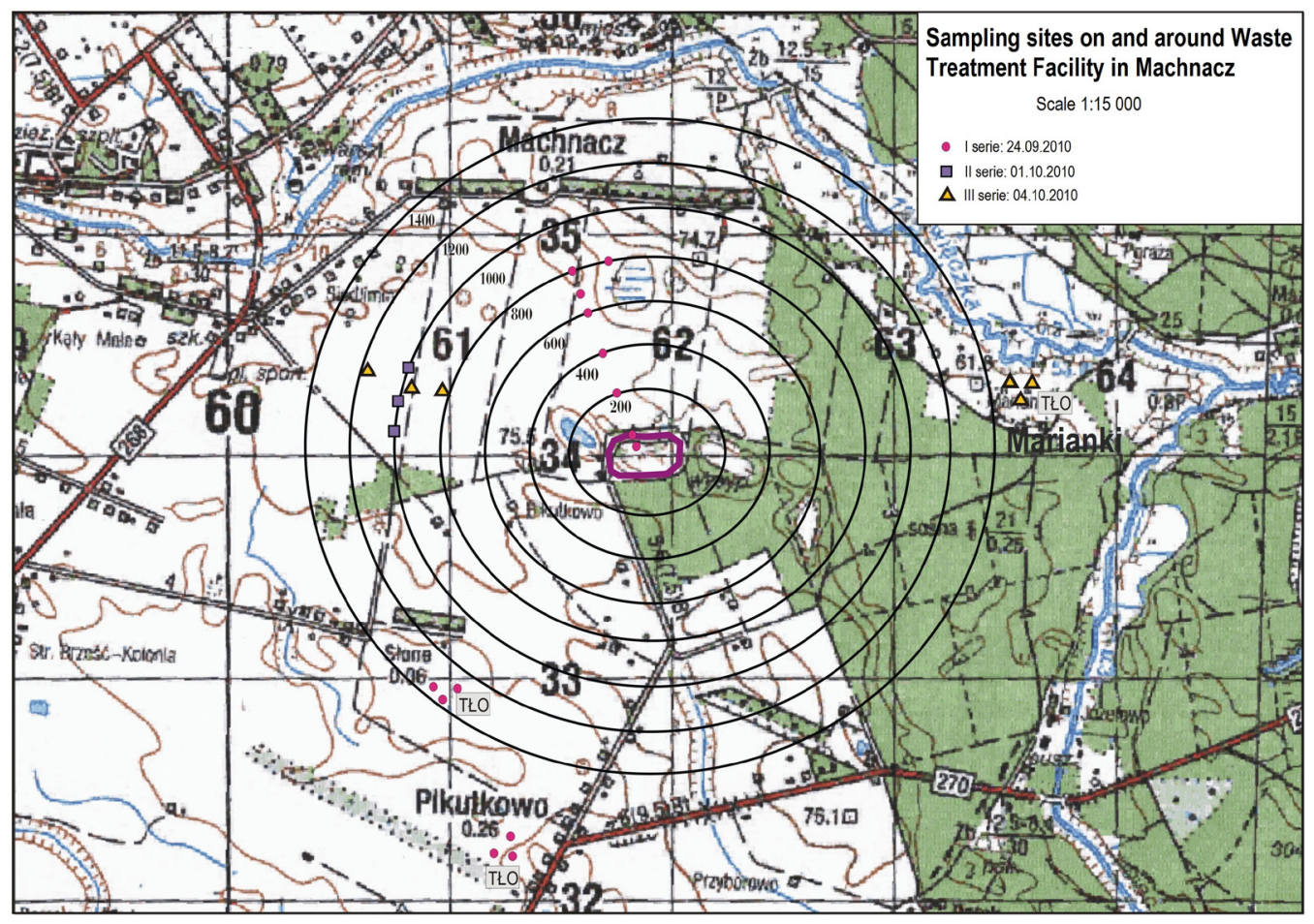

Fig. 1. Location of sampling sites during three sampling series. 


\section{RESULTS}

\subsection{Meteorological conditions}

In table 1, the results of the meteorological measurements and observations made during the field studies on and around the landfill site are presented.

In the present study, temperature ranged between 8 and $23^{\circ} \mathrm{C}$, humidity between 45.6 and $60.4 \%$ and wind speed between 2.3 and $5.4 \mathrm{~m} / \mathrm{s}$. Results of the observations and meteorological measurements indicate that during sampling period the weather conditions were favourable for collection of air samples for the microbiological studies.

3.2. Bioaerosol concentration in the air of the control sites In table 2, the concentrations of indicator microorganisms in the air collected in the control sampling sites are presented.

\subsection{Downwind concentration}

The sampling of bioaerosol around the landfill was made in three series in selected sampling sites. In series I, the samples were collected on the landfill site and every $200 \mathrm{~m}$ downwind from the area of the landfill. The results are presented in table 3.

In series II, the sampling site was located at a distance of $1000 \mathrm{~m}$ downwind from the landfill. The three sampling points were spread on an arc $100 \mathrm{~m}$ from each other (Fig. 1). The results of the sampling are presented in table 4 .

In series III, the samples were collected downwind from the landfill at increasing distances; the first sampling site was located at $800 \mathrm{~m}$ from the fence. The results are presented in table 5 .

The aggregated results are presented as a plot (Fig. 2).

Comparison of the quantitative data characterising the level of bioaerosol in the air collected from the sites located downwind from the landfill with the level of bioaerosol in the control air shows that there is a gradual decrease of landfill influence on the sanitary condition of air. The impact of the landfill ends at a distance of $1000-1200 \mathrm{~m}$ from the fence for $\beta$-haemolytic bacteria and yeast and yeast-like fungi.

Apart from determining the level of indicator microorganisms, the studies included identification of various genera of microorganisms grown on individual media. In samples collected along the fence, Enterobacteriaceae belonging to the genera Escherichia, Proteus, Enterobacter and Klebsiella were noted on the MCK medium. The same genera along with Serratia were noted in samples of air collected at a distance of 1000-1200 m from the fence. Samples of air collected in the control sites contained Enterobacteriaceae from the genera Escherichia, Proteus, Enterobacter and Klebsiella. Growth of cfu with a $\beta$-haemolysis zone was noted on the COS medium. Gram staining allowed determination of the presence of Gram-positive long cylindrical forms (bacilli), Gram-negative short cylindrical forms (coccobacilli) and Gram-positive diplococci. Air samples collected at a distance of $1200 \mathrm{~m}$ from the landfill indicate the presence of yeasts and yeast-like fungi on the SGC2 medium. On the basis of the morphological features and results of API $20 \mathrm{C}$ AUX microtest, the genus Candida was identified.

\section{DISCUSSION}

Field observations have shown that municipal waste management in the Machnacz landfill was carried out in accordance with the requirements of the existing regulations. However, the results obtained indicated that the landfill was the source of emission and dispersion of bacterial and fungal aerosol. Thus, despite correct exploitation and proper application of technological processes of waste landfilling, the landfill was the cause of deteriorated microbiological quality of air in its surroundings.

To assess the range of the landfill influence on microbial air quality, the concentration of indicator microorganisms in individual sampling points was compared with concentration of these

Table 1. The results of meteorological measurements and observations

\begin{tabular}{|c|c|c|c|c|}
\hline Data and series no. & Wind direction & $\begin{array}{c}\text { Wind speed }\left(^{*}\right) \\
{[\mathbf{m} / \mathbf{s}]}\end{array}$ & $\begin{array}{c}\text { Air humidity }\left({ }^{* *}\right) \\
{[\%]}\end{array}$ & $\begin{array}{c}\text { Air temperature } \\
{\left[{ }^{\circ} \mathbf{C}\right]}\end{array}$ \\
\hline $\begin{array}{c}24.09 .2010 \\
\text { series I }\end{array}$ & S, SSE, SSW & 2.3 & 45.6 & $18-23$ \\
\hline $\begin{array}{c}1.10 .2010 \\
\text { series II }\end{array}$ & E, ESE & $4.5-5.4$ & 60.4 & $8-14$ \\
\hline $\begin{array}{c}4.10 .2010 \\
\text { series III }\end{array}$ & E, ENE, ESE & 3.5 & 60.0 & $12-15$ \\
\hline
\end{tabular}

$\left.{ }^{*}\right)$ average of 10 measurements

$\left.{ }^{* *}\right)$ average of five measurements

Table 2. Average concentrations of indicator microorganisms in the air of control sampling sites

\begin{tabular}{|l|c|c|c|}
\hline \multirow{2}{*}{ Sampling site } & \multicolumn{3}{|c|}{ Concentration of microorganisms [cfu/m ${ }^{3}$ ] } \\
\cline { 2 - 4 } & $\begin{array}{c}\text { Bacteria from the } \\
\text { Enterobacteriaceae family }\end{array}$ & $\beta$-Haemolytic bacteria & Yeasts and yeast-like fungi \\
\hline Pikutkowo & 16 & 5 & 3 \\
\hline Marianki & 8 & 4 & 1 \\
\hline Słone & 14 & 5 & 3 \\
\hline Wieniec Zdrój & 10 & 6 & 1 \\
\hline Average & 12 & 5 & 2 \\
\hline
\end{tabular}

$\mathrm{cfu} / \mathrm{m}^{3}$, colony forming units per cubic metre of air. 
microorganisms in control sites. The sampling point where levels of the selected indicator microorganisms were equal to the values in the control sites indicated the range of the impact.

\subsection{Bioaerosol concentration in the air of the control sites} The sampling of bioaerosol in the control sites was carried out at a significant distance from the landfill, excluding the influence of the facility on the result of the analysis. The presence of bacteria from the Enterobacteriaceae family at $8-16 \mathrm{cfu} / \mathrm{m}^{3}$ (on average $12 \mathrm{cfu} / \mathrm{m}^{3}$ ), $\beta$-haemolytic bacteria at $4-6 \mathrm{cfu} / \mathrm{m} 3$ (on average $5 \mathrm{cfu} / \mathrm{m}^{3}$ ) as well as yeasts and yeast-like fungi at $1-3 \mathrm{cfu} / \mathrm{m}^{3}$ (on average $2 \mathrm{cfu} / \mathrm{m}^{3}$ ) has been determined in these sites.

Average microbial concentrations found in the present study were in agreement with those reported in the literature despite the use of different methodologies. In these studies, the concentrations of bacteria from the Enterobacteriaceae family in control air were at the levels from 2 to $6 \mathrm{cfu} / \mathrm{m}^{3}$ (city air) [Donderski et al. 2005], from $<0.4$ to $7.9 \mathrm{cfu} / \mathrm{m}^{3}$ (residential area: meadow and unpaved road) [Zucker, Muller 2004], from 2 to $5 \mathrm{cfu} / \mathrm{m}^{3}$ (around two cities) and from 1 to $2 \mathrm{cfu} / \mathrm{m}^{3}$ (around two villages) [Vilavert et al. 2009]. In the vicinity of the landfill facilities, the concentrations in the control sites reached from 13 to $26 \mathrm{cfu} / \mathrm{m}^{3}$ (100 m upwind from the waste handling place) [Nadal et al. 2009], from 12 to $20 \mathrm{cfu} / \mathrm{m}^{3}$ (300 m upwind from the facility) [Lavoie, Alie 1997], from 0 to $14 \mathrm{cfu} / \mathrm{m}^{3}$ (50-200 $\mathrm{m}$ upwind from the waste recovery plant) [Kiviranta et al 1999] and from 3.3 to $15.8 \mathrm{cfu} / \mathrm{m}^{3}$ ( $40 \mathrm{~m}$ upwind from the facility) [Grisoli et al. 2009].

The studies of $\beta$-haemolytic bacteria and yeast and yeast-like fungi are not so numerous. The concentrations of $\beta$-haemolytic bacteria in control air determined in other studies reached from 0 to $10 \mathrm{cfu} / \mathrm{m}^{3}$ depending on the month of the analysis (100 m upwind from the landfill) [Berleć et al. 2009].

The concentration of yeasts and yeast-like fungi in the control air reached up to $3 \mathrm{cfu} / \mathrm{m}^{3}$ (empty room in the building beyond the landfill) [Coccia et al. 2010] and from 0 to $300 \mathrm{cfu} / \mathrm{m}^{3}$ (upwind from the landfill) depending on the time of the year [Filipkowska et al. 2008]. In the studies performed around other facilities, the median concentration of yeasts in control site $(500 \mathrm{~m}$ upwind from the WWTP) was $63 \mathrm{cfu} / \mathrm{m}^{3}$ [Gotkowska-Płachta et al. 2013].

The concentration of haemolytic bacteria in control air indicated that the air was polluted even in sites presently not subject to direct influence of the landfill. The probable reason for the presence of microorganisms in atmospheric air collected from the apparently clean sites may be the hypothetical mechanism of microorganism spreading [Kaźmierczuk et al. 2004]. At variable wind directions, microorganisms emitted from the landfill are gradually deposited, forming secondary sources of emission and dispersing over a significantly larger area. It may be assumed that after some time, they may be present in the air in a random locality regardless of the wind direction. As a result of this process, sites located upwind from the landfill could have been subjected earlier to the direct influence of the facility similarly as the sites located downwind. Therefore, it may be concluded that an active municipal waste landfill may also be a secondary cause of the microbial air pollution in its surrounding, regardless of the current wind direction.

\subsection{Downwind concentration}

Comparison of quantitative data characterising the bioaerosol pollution of air collected in the sampling sites downwind from the facility (tables 3, 4 and 5) with air from control sites (table 2) allowed stating that with the increasing distance from the facility, a decreasing trend in the concentrations of all the microbial types generally appeared. All the sampled microorganisms showed the maximum level in the downwind site nearest to the facility. At distances between 1000 and $1200 \mathrm{~m}$ from the fence, a gradual decrease of the landfill influence on the air quality was noted. In the samples of air collected in sites located at $1200 \mathrm{~m}$ from the fence of the facility (Fig. 1):

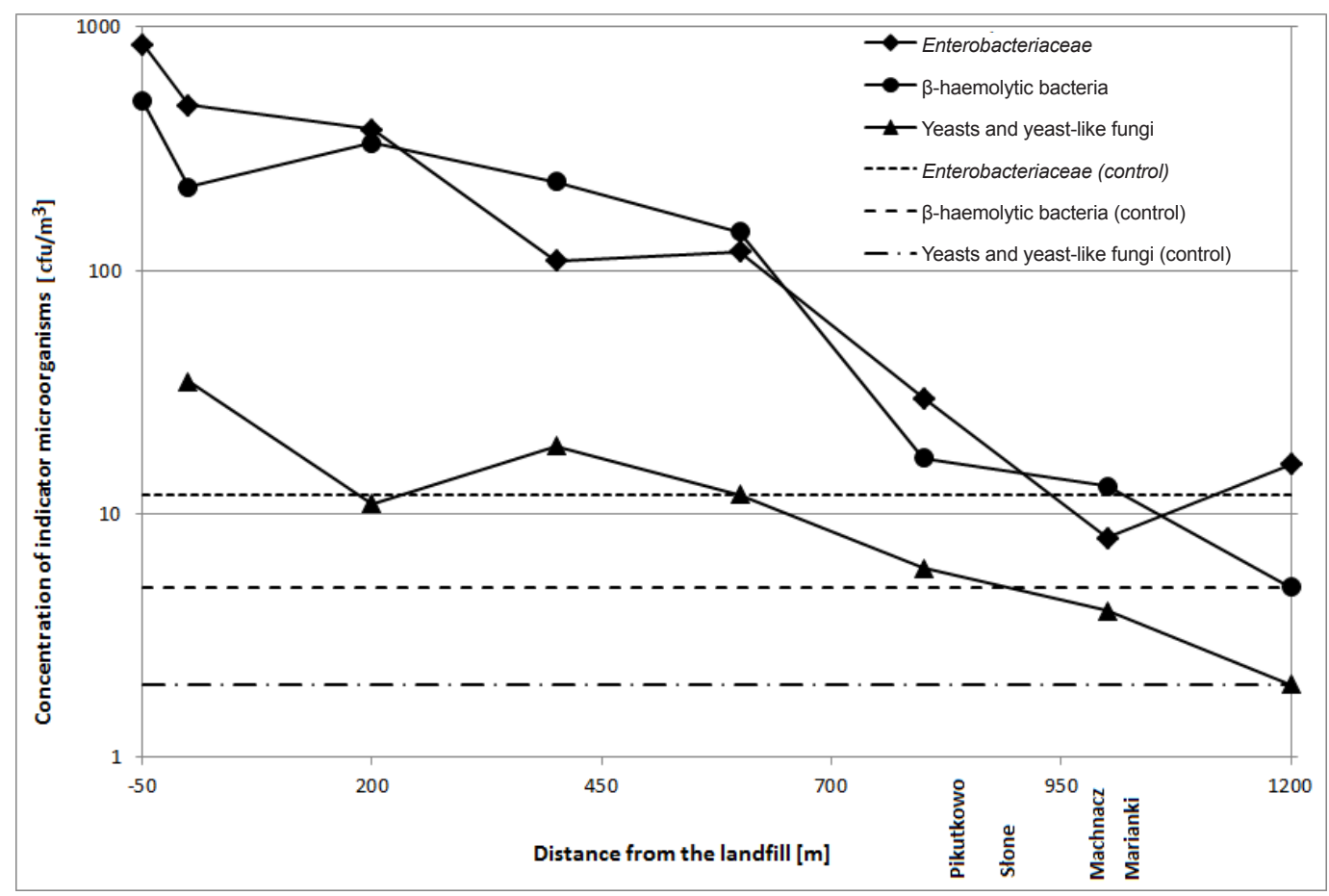

Fig. 2. Relationship between indicator microorganism concentrations and distance from the landfill fence. 
Table 3. Average concentrations of indicator microorganisms in the air of control sampling sites.

\begin{tabular}{|c|c|c|c|}
\hline \multirow{2}{*}{ Sampling site } & \multicolumn{3}{|c|}{ Concentration of microorganisms [cfu/m ${ }^{3}$ ] } \\
\hline & $\begin{array}{c}\text { Bacteria from the } \\
\text { Enterobacteriaceae family }\end{array}$ & $\beta$-Haemolytic bacteria & Yeasts and yeast-like fungi \\
\hline$-50 \mathrm{~m}$ (within the landfill) & 850 & Uncountable & - \\
\hline $0 \mathrm{~m}$ (fence) & 480 & 220 & 35 \\
\hline$+200 \mathrm{~m}$ & 380 & 335 & 11 \\
\hline$+400 \mathrm{~m}$ & 110 & 231 & 19 \\
\hline$+600 \mathrm{~m}$ & 120 & 144 & 6 \\
\hline
\end{tabular}

$\mathrm{cfu} / \mathrm{m}^{3}$, colony forming units per cubic metre of air.

Table 4. Average concentrations of indicator microorganisms in the air of control sampling sites.

\begin{tabular}{|c|c|c|c|}
\hline \multirow[b]{2}{*}{ Sampling site } & \multicolumn{3}{|c|}{ Concentration of microorganisms $\left[\mathrm{cfu} / \mathrm{m}^{3}\right]$} \\
\hline & $\begin{array}{c}\text { Bacteria from the } \\
\text { Enterobacteriaceae family }\end{array}$ & $\beta$-Haemolytic bacteria & Yeasts and yeast-like fungi \\
\hline +1000 m (1 $1^{\text {st }}$ point $)$ & 8 & 13 & 4 \\
\hline$+1000 \mathrm{~m}\left(2^{\text {nd }}\right.$ point $)$ & 8 & 11 & 4 \\
\hline +1000 m (3 ${ }^{\text {rd }}$ point $)$ & 8 & 13 & 4 \\
\hline
\end{tabular}

$\mathrm{cfu} / \mathrm{m}^{3}$, colony forming units per cubic metre of air.

Table 5. Average concentrations of indicator microorganisms in the air of control sampling sites.

\begin{tabular}{|c|c|c|c|}
\hline \multirow[b]{2}{*}{ Sampling site } & \multicolumn{3}{|c|}{ Concentration of microorganisms $\left[\mathrm{cfu} / \mathrm{m}^{3}\right]$} \\
\hline & $\begin{array}{c}\text { Bacteria from the } \\
\text { Enterobacteriaceae family }\end{array}$ & $\beta$-Haemolytic bacteria & Yeasts and yeast-like fungi \\
\hline$+800 \mathrm{~m}$ & 30 & 17 & 6 \\
\hline$+1000 \mathrm{~m}$ & 8 & 11 & 4 \\
\hline$+1200 \mathrm{~m}$ & 16 & 5 & 2 \\
\hline
\end{tabular}

$\mathrm{cfu} / \mathrm{m}^{3}$, colony forming units per cubic metre of air.

- the concentration of bacteria from the Enterobacteriaceae family slightly exceeded its concentration in the control air,

- the concentration of $\beta$-haemolytic bacteria as well as concentration of yeasts and yeast-like fungi were equal to their average concentrations in the control air.

Similar results were obtained in other studies of bioaerosols around municipal waste landfills. Breza-Boruta and Paluszak [2009] carried out microbiological analysis within and around municipal waste landfills. Despite correct landfill management, the facilities were significant sources of emission and dispersion of bacterial aerosol. The analysed air was strongly polluted with pathogenic staphylococci and actinobacteria, regardless whether the samples were collected directly on the landfill or in its surroundings. The determined concentrations of Escherichia coli in the air of studied landfills reached on average from 3.3 to 62 $\mathrm{cfu} / \mathrm{m}^{3}$ and of Salmonella sp. from 7 to $80.5 \mathrm{cfu} / \mathrm{m}^{3}$, whereas at a distance of 150-200 $\mathrm{m}$ from the facilities, their concentrations were from 4 to $12 \mathrm{cfu} / \mathrm{m}^{3}$ and from 0 to $8 \mathrm{cfu} / \mathrm{m}^{3}$, respectively. Another study carried out on a municipal waste landfill serving ca. 100,000 inhabitants determined the presence of Escherichia coli and yeasts [Jurkiewicz et al. 1998]. In the direct neighbourhood of the active sector, the concentration of Escherichia coli reached, depending on the measuring series, from 79 to $470 \mathrm{cfu} / \mathrm{m}^{3}$. At a distance of $100 \mathrm{~m}$ downwind from the landfill, the concentrations reached from 0 to $157 \mathrm{cfu} / \mathrm{m}^{3}$. At a distance of $150 \mathrm{~m}$, the presence of these bacteria was not noted. The concentrations of Salmonella sp., Escherichia coli and other bacteria of the family Enterobacteriaceae determined in the air samples taken on municipal solid landfill accepting ca. $150,000 \mathrm{Mg}$ of waste yearly were from 0 to $180 \mathrm{cfu} / \mathrm{m}^{3}$, from 2 to $130 \mathrm{cfu} / \mathrm{m}^{3}$ and from 0 to $1740 \mathrm{cfu} / \mathrm{m}^{3}$ respectively, depending on the month of the sampling [Breza-Boruta 2012]. The concentration of these microorganisms in the air at a distance $200 \mathrm{~m}$ from the facility were from 0 to $8 \mathrm{cfu} / \mathrm{m}^{3}$ in the case of Salmonella sp. and Escherichia coli, and from 0 to $20 \mathrm{cfu} / \mathrm{m}^{3}$ in the case of other bacteria of the family Enterobacteriaceae.

In the previously mentioned study [Jurkiewicz et al. 1998], the determined air concentrations of yeasts reached from 786 to $21379 \mathrm{cfu} / \mathrm{m}^{3}$ on the landfill and from 0 to $1493 \mathrm{cfu} / \mathrm{m}^{3}$ at a distance of $150 \mathrm{~m}$ from the landfill. In other studies, the average levels of yeasts in the air of the landfill undergoing closure were from 224 to $1788 \mathrm{cfu} / \mathrm{m}^{3}$ depending on the season and year of sampling [Huang et al. 2002].

Analysing the results of microbiological studies of air carried out on a municipal waste landfill and in its surroundings, Berleć et al. [2009] stated that it is a source of pathogenic microorganisms that may pose direct hazard to human health. The determined concentration of $\beta$-haemolytic staphylococci in the air of the central part of the landfill reached from 12 to $80 \mathrm{cfu} / \mathrm{m}^{3}$, depending on the month of the analysis, and from 0 to $36 \mathrm{cfu} / \mathrm{m}^{3}$ at a distance of $300 \mathrm{~m}$ downwind from the source of emission.

The results of aerosol sampling conducted on two landfill sites indicated [Zmysłowska et al. 2007] that haemolytic bacteria were 
abundant in atmospheric air and their average concentration oscillated between 30 and $5337 \mathrm{cfu} / \mathrm{m}^{3}$. More abundant with haemolytic bacteria were active sectors of the landfill and areas adjacent to the entrance road. A higher number of potentially hazardous strains of bacteria in the air were related to the routine maintenance of facilities and a regular supply of wastes.

Rahkonen et al. [1990] observed that bacterial aerosol in municipal waste landfills was composed mainly of opportunistic pathogens that could cause infectious diseases in humans with immune deficiency. The bioaerosol was dominated by bacteria from the genera Pseudomonas, Enterobacter and Bacillus. These bacteria may pose particular hazard to the health of people spending much time within the landfill and in its surroundings. Their analyses on two large municipal waste landfills in Finland have indicated that the concentrations of Gram-negative bacteria in $67 \%$ of the collected samples of air were higher that the proposed threshold value of $1000 \mathrm{cfu} / \mathrm{m}^{3}$.

\subsection{Range}

The range of the influence of the Machnacz landfill on the microbial air quality based on a proposed assessment may be estimated as $1000-1200 \mathrm{~m}$ from the fence of the facility. The impact of the landfill affects mainly areas to the north and south from the site because in these directions numerous houses and farm buildings are located. The influence of the landfill reaches the houses and farm buildings located in the neighbouring villages.

Similar results have been obtained in other studies focused on determining the range of bioaerosol dispersion around waste management installations. Barabasz and others [Barabasz et al 2006, Barabasz et al. 2001, Barabasz et al. 2002] have conducted microbiological analysis of atmospheric air on different municipal waste landfills. Their results allowed them to state that with regard to aerosanitary conditions the air within the landfill and in its nearer and farther surroundings was equally polluted with microorganisms such as bacteria, including actinomycetes, and fungi. The air quality standards were exceeded on the landfill as well as in other sites that at first were considered relatively clean and were set as the control sites and were supposed to act as the background for comparative studies. The determined microorganisms included two pathogenic bacteria species and seven pathogenic fungi species, including those producing toxins.

Based on studies carried out in the Tarnów-Krzyż landfill, Frączek et al. [2003] determined that in 9 out of 10 reception points, even at distances of $1000 \mathrm{~m}$ from the landfill, the air was microbiologically contaminated at a level considered as strongly polluted.

The present study has shown that the air sampled directly on the municipal solid waste landfill is abundant with microorganisms of different taxonomic groups. The landfill in Machnacz - similar to many other landfills - is a source of emission of saprophytic, pathogenic and relatively pathogenic (opportunistic) microorganisms. The increased concentration of microorganisms in the air does not necessarily mean a proportionally higher hazard for people spending time in the landfill area. However, higher concentration of pathogenic microorganisms in the air increases the probability of their contact with humans, penetration through the respiratory system or skin into the organism and developing specific symptoms. Higher concentration of relatively pathogenic or pathogenic microorganisms may cause potentially higher possibility of infections in humans and animals.

Examples of landfills that are modern, well-organised and correctly managed indicate that the microbial air quality of the landfill does not depend on the type of technology or the maintenance. Microbial air pollution results from the presence of mineral and organic substances in the municipal waste, which are a source of nourishment for many microorganism groups, including pathogenic, potentially pathogenic or opportunistic forms. The range of the influence largely depends on the geographic conditions around the facility and probably only to a slight degree on the applied waste management and exploitation technology.

\section{CONCLUSIONS}

The studied municipal solid waste landfill in Machnacz is the source of bioaerosol emission despite its correct management. The use of proposed indicator microorganisms - bacteria from Enterobacteriaceae family, $\beta$-haemolytic bacteria and yeasts and yeast-like fungi - allowed for assessing the range of exposure for the surroundings. The emission range was maximum for $\beta$-haemolytic bacteria and yeasts and yeast-like fungi and reached $1200 \mathrm{~m}$ from the landfill fence.

In samples collected along the fence, Enterobacteriaceae belonging to the genera Escherichia, Proteus, Enterobacter and Klebsiella were noted. The same genera along with Serratia were noted in samples of air collected at a distance of 1000-1200 m from the fence. With Gram staining, Gram-positive bacilli and diplococcic and Gram-negative coccobacilli were determined. Among the yeasts, the genus Candida was identified.

\section{REFERENCES AND LEGAL ACTS}

ADAMIAK W., KOŁWZAN B., SAROWSKAJ. 2001. Qualitative assessment of the bioaerosol in the surroundings of Maślice landfill in Wrocław. Environment Protection Engineering 27: 27-42.

BARABASZ W., ALBIŃSKA D., BARABASZ J. 2006. Obiekty komunalne jako źródła bioaerozolu i mikroorganizmów szkodliwych dla zdrowia. Agricultural University of Kraków.

BARABASZ W., FRACCZEK K., GRZYB J., MARCINOWSKA K., BIS H., CHMIEL M., BARABASZ J., KOSIŃSKA B., FERTIG P. 2002. Wpływ wielkości składowiska odpadów i czasu jego eksploatacji na zanieczyszczenie mikroorganizmami powietrza atmosferycznego. Mat. VI Konf. Nauk.-Techn. Gospodarka odpadami komunalnymi. Koszalin-Kołobrzeg, 19-38.

BARABASZ W., GRZYB J., FRĄCZEK K., ALBIŃSKA D., KULTY

T., KRÓL H., FLAK K., KORNAŚ G., BARABASZ J., PAWLAK

K., SICIAK K. 2001. Pięcioletni mikrobiologiczny monitoring powietrza atmosferycznego na składowisku odpadów komunalnych Barycz w Krakowie. Mat. VII Konferencji Naukowo-Technicznej Gospodarka odpadami komunalnymi. Koszalin-Kołobrzeg, 157-178.

BERLEĆ K., BUDZIŃSKA K., SZEJNIUK B., KUŁAKOWSKA A. 2009. Ocena oddziaływania składowiska odpadów komunalnych na wybrane parametry mikrobiologiczne powietrza. Rocznik Ochrona Środowiska 11: 1317-1328.

BREZA-BORUTA B. 2012. Bioaerosols of the municipal waste landfill site as a source of microbiological air pollution and health hazard. Ecological Chemistry And Engineering A 19: 851-862.

BREZA-BORUTA B., PALUSZAK Z. 2009. Wpływ zakładów utylizacji odpadów komunalnych na zanieczyszczenie mikrobiologiczne powietrza. Przemysł Chemiczny 88: 406-409. 
BUCZYŃSKA A., CYPROWSKI M., SZADKOWSKA-STAŃCZYK I. 2006. Czynniki biologiczne, szkodliwe dla zdrowia, występujace w powietrzu na terenie składowisk odpadów komunalnych. Medycyna Pracy 57: 531-535.

BURKOWSKAA., SWIONTEK-BRZEZINSKA M., KALWASIŃSKA A. 2011. Impact of the municipal landfill site on microbiological contamination of air. (In:) Contemporary Problems of Management and Environmental Protection. Some aspects of environmental impact of waste dumps no 9 (Ed: Skibniewska K.A.), University of Warmia and Mazury in Olsztyn: Olsztyn, 71-87.

BUTAREWICZ A., KOWALUK-KRUPA A. 2004. Mikrobiologiczne zanieczyszczenie powietrza atmosferycznego na terenie i wokół składowiska odpadów komunalnych w Augustowie. Ochrona Powietrza i Problemy Odpadów 38: 167-173.

COCCIA A. M., GUCCI P. M. B., LACCHETTI I., PARADISO T., SCAINI F. 2010. Airborne microorganisms associated with waste management and recovery: biomonitoring methodologies. Annali dell'Istituto Superiore di Sanità 46: 288-292.

CROOK B., HIGGINS S., LACEY J. 1987. Airborne Gram negative bacteria associated with the handling of domestic waste (In:) Advances in Aerobiology (Ed: Leuschner R.), Birkhauser: Basel, 371-375.

CURTIS L., REA W., SMITH-WILLIS P., FENYVES E., PAN Y. 2006. Adverse health effects of outdoor air pollutants. Environment International 32: 815-830.

DEL CIMMUTO A., D'ACUNZO F., MARINELLI L., DE GIUSTI M., BOCCIA A. 2010. Microbiological air quality in an urban solid waste selection plant. Italian Journal of Public Health 7: 20-27.

DONDERSKI W., WALCZAK M., PIETRZAK M. 2005. Microbiological contamination of air within the city of Torun. Polish Journal of Environmental Studies 14: 223-230.

DOUWES J., THORNE P., PEARCE N., HEEDERIK D. 2003. Bioaerosol health effects and exposure assessment: progress and prospects. Review. Annals of Occupational Hygiene 47: $187-200$

DUTKIEWICZ J. 1997. Bacteria and fungi in organic dust as potential health hazard. Annals of Agricultural and Environmental Medicine 4: 11-16.

FILIPKOWSKA Z., GOTKOWSKA-PŁACHTAA., KORZENIEWSKA E. 2008. Grzyby pleśniowe oraz drożdże i grzyby drożdżoidalne w powietrzu atmosferycznym na terenie i w otoczeniu oczyszczalni ścieków z systemem stawów napowietrzanych i stabilizacyjnych. Woda - Środowisko - Obszary Wiejskie 8: 69-82.

FRĄCZEK K., BARABASZ W. 2004. Składowisko odpadów komunalnych w Tarnowie-Krzyżu jako źródło mikrobiologicznych czynników szkodliwych dla środowiska i zdrowia człowieka. Przegląd Lekarski 61 (Suppl. 3): 36-39.

FRACCZEK K., MARCINOWSKA K., BARABASZ W., GRZYB J. 2003. Occurrence of fungi in the atmospheric air within the range of municipal waste dump influence in Ujków Stary, Cracow and Tarnów. Polish Journal of Natural Sciences 15: 591-596.

GIUSTI L. 2009. A review of waste management practices and their impact on human health. Waste management 29: 2227-2239.

GOTKOWSKA-PŁACHTA A., FILIPKOWSKA Z., KORZENIEWSKA E., JANCZUKOWICZ W., DIXON B., GOŁAŚ I., SZWALGIN D. 2013. Airborne microorganisms emitted from wastewater treatment plant treating domestic wastewater and meat processing industry wastes. Clean Soil, Air, Water 41: 429-436.

GRISOLI P., RODOLFI M., VILLANI S., GRIGNANI E., COTTICA D., BERRI A., PICCO A.M., DACARRO C. 2009. Assessment of airborne microorganism contamination in an industrial area characterized by an open composting facility and a wastewater treatment plant. Environmental Research 109: 135-142.
HELDAL K. K., HALSTENSEN A. S., THORN J., DJUPESLAND P., WOUTERS I., EDUARD W., HALSTENSEN T. S. 2003. Upper airway inflammation in waste handlers exposed to bioaerosols. Occupational and Environmental Medicine 60: 444-451.

HUANG C.Y., LEE C.-C, LI F.-C., MA Y.-P., JENNY SU H.-J. 2002. The seasonal distribution of bioaerosols in municipal landfill sites: a 3-yr study. Atmospheric Environment 36: 4385-4395.

JARZĄB A., GÓRSKA-FRACZZEK S., RYBKA J., WITKOWSKA D. 2011. Zakażenia pałeczkami jelitowymi - diagnostyka, oporność na antybiotyki i profilaktyka. Postępy Higieny i Medycyny Doświadczalnej 65: 55-72.

JURKIEWICZ G., MARKIEWICZ P., SKORUPSKI W. 1998. Zorganizowane składowisko odpadów komunalnych jako źródło zanieczyszczeń powietrza. Chemia i Inżynieria Ekologiczna 5: 583-593.

KAARAKAINEN P., MEKLIN T., RINTALA H., HYVÄRINEN A., KÄRKKÄINEN P., VEPSÄLÄINEN A., HIRVONEN M.-R., NEVALAINEN A. 2008. Seasonal variation in airborne microbial concentrations and diversity at landfill, urban and rural sites. Clean Soil, Air, Water 36: 556-563.

KAŹMIERCZUK M. 1996. Badania powietrza w rejonie wysypiska komunalnego dla m. Starachowice w Marcinkowie Dolnym, Gm. Wachock. Raport. IOŚ: Warszawa.

KAŹMIERCZUK M., KALISZ L. 1998-2000. Opracowanie zasad sporządzania ocen warunków aerosanitarnych wokół komunalnych oczyszczalni ścieków i wysypisk. Etap I - III. IOŚ, Warszawa.

KAŹMIERCZUK M., KALISZ L. 2001. Ocena warunków aerosanitarnych na terenie wysypisk odpadów komunalnych. Ochrona Środowiska i Zasobów Naturalnych 21/22: 25-34.

KAŹMIERCZUK M., KALISZ L., SAŁBUT J. 2004. Mikrobiologiczne zanieczyszczenia powietrza w otoczeniu obiektów gospodarki komunalnej. Monografia. Instytut Ochrony Środowiska, Warszawa.

KIVIRANTA H., TUOMAINEN A., REIMAN M., LAITINEN S., NEVALAINEN A., LIESIVUORI J. 1999. Exposure to airborne microorganisms and volatile organic compounds in different types of waste handling. Annals of Agricultural and Environmental Medicine 6: 39-44.

KRAJEWSKI J.A., SZARAPIŃSKA-KWASZEWSKA J., DUTKIEWICZ B., CYPROWSKI M. 2001. Drobnoustroje żywe występujące w powietrzu na stanowiskach pracy w zakładach zajmujacych się utylizacja odpadów komunalnych. Medycyna Pracy 52: 343-349.

KULIG A., OSSOWSKA-CYPRYK K. 1999. Problematyka badań mikrobiologicznych $w$ ocenie oddziaływania na środowisko obiektów komunalnych - zagadnienia metodyczne. Problemy Ocen Środowiskowych 1: 51-58.

KUMMER V., THIEL W. R. 2008. Bioaerosol - sources and control measures. International Journal of Hygiene and Environmental Health 211: 299-307.

LAVOIE J., ALIE R. 1997. Determining the characteristics to be considered from a worker health and safety standpoint in household waste sorting and composting plants. Annals of Agricultural and Environmental Medicine 4: 123-128.

LIEBERS V., RAULF-HEIMSOTH M., BRÜNING T. 2008. Health effects due to endotoxin inhalation (review). Archives of Toxicology 82: 203-210.

LIS D. O., PASTUSZKA J., ULFIG K. 1999. Mikrobiologiczna jakość powietrza w pomieszczeniach administracyjno-biurowych wysypiska odpadów komunalnych na przykładzie Miejskiego Zakładu Składowania Odpadów w Sosnowcu. Ochrona Powietrza i Problemy Odpadów 33: 199-202. 
LIS D. O., ULFIG K., WLAZŁO A., PASTUSZKA J.S. 2004. Microbial air quality in offices at municipal landfills. Journal of Occupational and Environmental Hygiene 1: 62-68.

MAŁECKA-ADAMOWICZ M., KACZANOWSKA J., DONDERSKI W. 2007. The impact of a landfill site in Żółwin - Wypaleniska on the microbiological quality of the air. Polish Journal of Environmental Studies 16: 101-107.

MARCHAND G., LAVOIE J., LAZURE L. 2012. Evaluation of bioaerosols in a municipal solid waste recycling and composting plant. Journal of the Air \& Waste Management Association 45: 778-781.

MARTHI B., FIELAND V.P., WALTER M., SEIDLER R.J. 1990. Survival of bacteria during aerosolisation. Applied Environmental Microbiology 56: 3463-3467.

MENICHETTI F. 2005. Current and emerging serious Gram-positive infections. Clinical Microbiology and Infection 11 Suppl 3: 22-28.

NADAL M., INZA I., FIGUERAS M. J., DOMINGO J. L. 2009 Health risks of the occupational exposure to microbiological and chemical pollutants in a municipal waste organic fraction treatment plant. International Journal of Hygiene and Environmental Health 212: 661-669.

PARK D.-U., RYU S.-H., KIM S.-B., YOON Ch.-S. 2011. An assessment of dust, endotoxin, and microorganism exposure during waste collection and sorting. Journal of the Air \& Waste Management Association 61: 461-468.

PN 89/Z-04008. 1998. Ochrona czystości powietrza. Pobieranie próbek. Pobieranie próbek powietrza atmosferycznego (imisja) do badań mikrobiologicznych metodą aspiracyjną i sedymentacyjna. PKN. 1998. Warszawa.

PN 89/Z-04111.01. 1998. Ochrona czystości powietrza. Badania mikrobiologiczne. Postanowienia ogólne i zakres normy. PKN. 1998. Warszawa.

POURCHER A., SUTRA L., HE I., BOLLET C., SIMONEAU P., GARDAN L. 2001. Enumeration and characterization of cellulolytic bacteria from refuse of a landfill. FEMS Microbiology Ecology 34: 229-241.

RAHKONEN P., ETTALA M., LAUKKANEN M., SALKINOJA-SALONEN M. 1990. Airborne microbes and endotoxins in the work environment of two sanitary landfills in Finland. Aerosol Science and Technology 13: 505-513.

SCHRAPP K., AL-MUTAIRI N. 2010. Associated health effects among residences near Jeleeb Al-Shuyoukh landfill. American Journal of Environmental Sciences 6: 184-190.

SHAFFER B. T., LIGHTHART B. 1997. Survey of culturable airborne bacteria at four diverse locations in Oregon: urban, rural, forest, and coastal. Microbial Ecology 34: 167-177.

SHELTON B. G., KIRKLAND K. H., FLANDERS W. D., MORRIS G. K. 2002. Profiles of airborne fungi in buildings and outdoor environments in the United States. Applied and Environmental Microbiology 68: 1743-1753.

TRACZEWSKA T. M., KARPIŃSKA-SMULIKOWSKA J. 2000. Wpływ składowiska odpadów komunalnych na jakość mikrobiologiczną powietrza. Ochrona Środowiska 2: 35-38.

TRAVERSI D., ALESSANDRIA L., SCHILIRÒ T., GILLI G. 2011. Size-fractionated PM10 monitoring in relation to the contribution of endotoxins in different polluted areas. Atmospheric Environment 45: 3515-3521.

VILAVERT L., NADAL M., INZA I., FIGUERAS M. J., DOMINGO J. L. 2009. Baseline levels of bioaerosols and volatile organic compounds around a municipal waste incinerator prior to the construction of a mechanical-biological treatment plant. Waste Management 29: 2454-2461.

WOUTERS I. M., HILHORST S. K. M., KLEPPE P., DOEKES G., DOUWES J., PERETZ C., HEEDERIK D. 2002. Upper airway inflammation and respiratory symptoms in domestic waste collectors. Occupational and Environmental Medicine 59: 106-112.

ZAREMBA L., BOROWSKI J. 2001. Mikrobiologia lekarska dla studentów medycyny. Podręcznik. Wydanie III, PZWL, Warszawa.

ZMYSŁOWSKA I., KORZEKWA K., POLITO M. 2007. Microbiological pollution of air around solid wastes disposal facility. Ochrona Środowiska i Zasobów Naturalnych 32: 161-165.

ZUCKER B.-A., MULLER W. 2004. Airborne endotoxins and airborne Gram-negative bacteria in a residential neighbourhood. Water, Air, and Soil Pollution 158: 67-75. 